\title{
Orthodontic upright treatment for mesioangular impacted lower second molar
}

\author{
Baekgue Choi ${ }^{1,2}$, Dongkee Jeong ${ }^{3}$, Sunghoon Lim4, Sungnam Gang ${ }^{4 *}$ \\ 'Gajirunhan S Dental Clinic, Gimpo, Republic of Korea \\ ${ }^{2}$ Graduate School of Chosun University, Gwangju, Republic of Korea \\ ${ }^{3} \mathrm{G}$ Coje Dental Clinic, Geoje, Republic of Korea \\ ${ }^{4}$ Department of Orthodontics, School of Dentistry, Chosun University, Gwangju, Republic of Korea
}

The lower $2^{\text {nd }}$ molar eruption is beginning to mesiolingually, then rotate to distobuccally so it has a tendency to be tilted and impacted mesially. Signs and symptoms of impacted $2^{\text {nd }}$ molar are similar to impacted $3^{\text {rd }}$ molar's. However, treatment plan for impacted $2^{\text {nd }}$ molar is different from that of impacted $3^{\text {rd }} s$. The former is the preservation and uprighting of $2^{\text {nd }}$ molar so that it could act to recovery of mastication, symmetrical facial growth, maintaining the symmetry of dental arch, stable occlusion, while the latter is the extraction of tooth. If the uprighting treatment is planned, most proper protocol of treatment and the additional treatment opition should be applied with consideration for it's crown exposure, present of $3^{\text {rd }}$ molar which interrupt the uprighting process, extrusion of opposite tooth. Although it could not improve the esthetic result, it could prevent many dental problems. Therefore, uprighting for impacted lower $2^{\text {nd }}$ molar is meaningful treatment. (J Dent Rehabil Appl Sci 2017;33(1):25-33)

Key words: impaction of lower second molar; minor tooth movement; orthodontic uprighting treatment

\section{서론}

치아의 매복(Impaction)은 맹출로 내의 물리적 장애 물이나 치배의 비정상적 위치에 의해 발생한 치아 맹출 의 정지로 정의할 수 있다. ${ }^{1}$ Andreasen 등은 매복을 맹출 장애라고 하면서 치배의 위치 이상, 맹출로 내의 장애물, 맹출 기전의 실패를 세 가지 주된 원인으로 지적한 바 있 다. ${ }^{2}$ 영구치의 매복은 하악 제 3 대구치에서 가장 흔하지 만, 하악 제 2 대구치의 매복은 상당히 드물어 Grover 등 ${ }^{3}$ 은 $0.03 \%$, Bondemark 등 ${ }^{4}$ 은 맹출로가 막힌 이소맹출은 $1.5 \%$, 매복은 $0.2 \%$ 의 발병률을 보고한 바 있다.

하악 제 2 대구치와 제 3 대구치의 치배는 하악골의 골체

*Correspondence to: Sungnam Gang

Assistant Professor, Department of Orthodontics, School of Dentistry, Chosun University, 309 Philmum-daero, Dong-gu, Gwangju, 61452, Republic of Korea Tel: +82-62-220-3874, Fax: +82-62-226-3090, E-mail: 022bracket@gmail.com Received: November 11, 2016/Last Revision: February 5, 2017/Accepted: February 9, 2017
\end{abstract}

부와 상행지가 만나는 부분에서 근심 경사되어 발육하다 가 하악골 상행지 전연부의 골개조에 의해 맹출 공간이 점차 확보되면 원심 협측으로 회전하면서 맹출한다고 알 려져 있다. ${ }^{5}$ 대구치의 충분한 맹출 공간을 위해서는 하악 골 상행지 전연이 상당히 흡수되어야 하는데, 성장 후반 기에 골흡수가 부족하여 맹출공간 부족으로 인한 매복 이 일어날 가능성이 있다.

매복된 하악 제 2 대구치는 대합치인 상악 제 2 대구치의 과도한 정출, 치아우식증, 치주염, 제 1 대구치의 원심측 치근흡수, 낭종의 형성, 부정교합, 치관주위염등 제 3 대 구치의 근심경사 매복 상황과 유사한 병적 상태를 유발 할 수 있다. 특히 제 1 대구치의 원심치경부 근처에서 치아 
우식증이 생기면 치료를 위한 기구접근이 상당히 어렵고 제한되어 치료 결과가 좋지 않으며, 치근부에 우식증이 발생된 경우 정상적인 수복 치료가 불가능할 수도 있다. 또 대합치인 상악 제 2 대구치가 정출된 경우 골격성 고정 원등을 이용한 압하 치료까지 고려해야 한다. 이 때문에 하악 제 2 대구치의 매복은 가능한 빨리 치료해야 만 여러 문제점들을 예방할 수 있다. 하지만 하악 제 2 대구치의 매 복은 특별한 증상이 없는 경우가 많아 환자가 인식하지 못하여 다른 치과 치료나 일상적인 치과검진 도중에 발 견되는 경우가 많기 때문에 ${ }^{6}$ 치과의사가 철저한 구강검 사를 통해 조기에 발견하여 적절한 시기에 치료해야 한 다. ${ }^{1,6}$ 영구 대구치는 치열의 정상적인 형성, 안면 성장의 조화, 정상적인 교합과 저작 기능을 위해 매우 중요한 역 할을 하는 것으로 알려져 있다. ${ }^{7}$ 심미성 개선을 위한 일반 적인 교정치료와 달리 매복된 하악 제 2 대구치의 직립 치 료는 교합기능의 개선, 치아우식증과 치주질환의 예방이 라는 의미를 가지는 치료이다. 하지만, 매복된 하악 제 2 대구치는 구강내에서 최후방 치아여서 접근이 어렵고 노 출된 임상치관의 길이가 짧아 원하는 위치에 교정장치를 부착하기 어려우며, 만약 치조골 내에 매복되어 치관부 가 노출되어 있지 않다면 치관 노출을 위한 부가적인 치 주외과적 처치가 필요하다. 대합치의 정출이나 제 3 대구 치의 존재는 매복된 하악 제 2대구치의 직립을 더욱 어렵 게 하는 요인들이다. 이에 본 증례 보고에서 저자들은 근 심경사 매복된 하악 제 2 대구치를 직립한 증례들을 소개 하고, 직립 치료중에 고려했던 사안들에 대해 서술하고 자 한다.

\section{증례보고}

증례 1

\section{초진 상태와 치료계획}

22세 여환이 입이 돌출되었다는 것을 주소로 내원하였 다. 교정치료를 위한 검진 결과 다른 문제점들도 있었지 만, \#47이 90 가량 mesial-in 회전된 상태로 근심경사 매 복되어 있었으며 치관의 대부분이 구강내로 노출되어 있 었다. 직립 치료에 방해되는 제 3 대구치나 연조직 증식, 대합치의 정출등은 관찰되지 않았다(Fig. 1). 이에 외과적 처치없이 노출된 치관에 교정장치를 부착하고 안정화 호 선으로 고정원을 확보하고 부가적인 초탄성 호선을 사용 하여 직립하기로 하였다.

\section{치료 과정}

\#47의 교합면에 .018" slot standard tube를 $90^{\circ}$ 회전 시켜 부착하였고, \#46의 협측면에는 .022" slot double tube를, \#45와 \#44에는 .022" slot bracket을 최대한 평 행하게 부착하였으며, \#44에서 \#46까지 교정력이 가해 지지 않도록 제작한 .019" $\times .025 "$ SS 안정호선을 결찰하 였다. \#46에 부착한 double tube의 보조 slot과 \#47 tube 간에는 .016" 초탄성 호선을 삽입하였다(Fig. 2A). \#47의 회전이 어느 정도 개선된 이후 .022" slot single tube를 올 바른 위치에 재부착하고 .016" 초탄성 호선과 stop clip (Split stop, SPEED system, Ontario, Canada)을 이용하 여 chicane spring을 만들어 원심 방향의 교정력을 지속
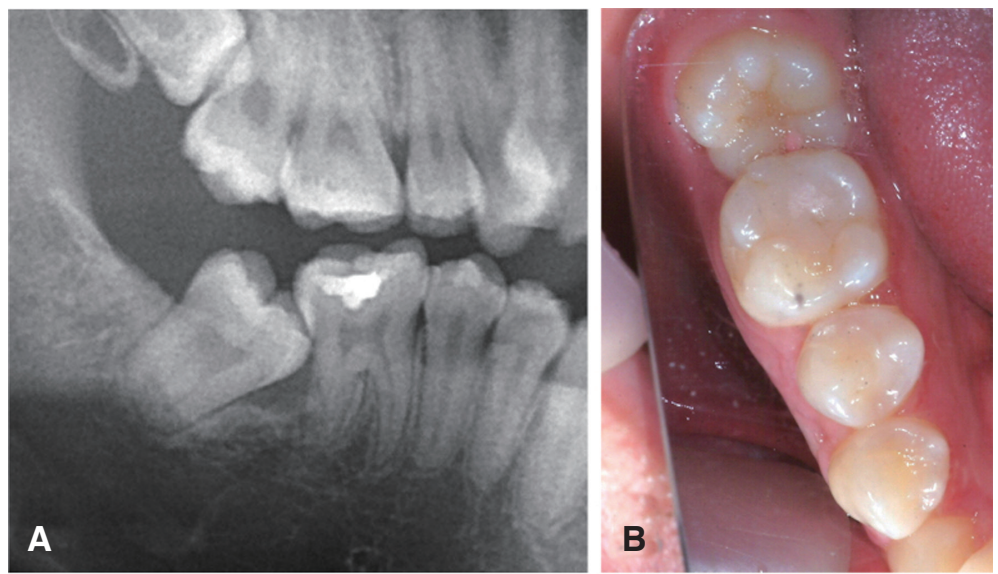

Fig. 1. Pretreatment panoramic radiograph (A), intraoral photograph (B). There were shown mesial angulated impaction of \#47. Especially, alveolar bone resorption was shown at \#47 mesial side in panoramic view. 

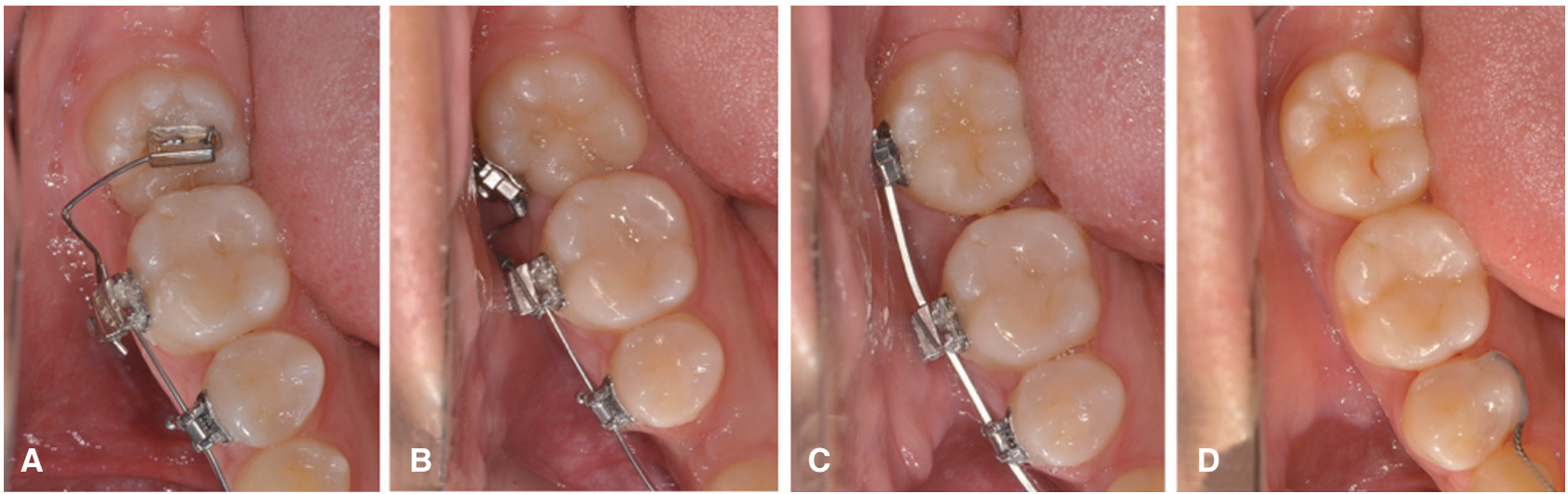

Fig. 2. Intraoral photographs during treat of mesioangulated impaction of \#47. Each images was cropped. (A) .018 standard tube was bonded on $\# 47$ occlusal surface by rotated $90^{\circ}$ then, auxillary wire was engaged. (B) .022 molar tube was bonded on \#47 buccal surface at rightly position. A chicane NiTi spring was delivered for continuous uprighting process. (C) After gross uprighting process, continuous main arch wire was engaged. (D) After treatment. The mesioangulated \#47 was uprighted to right position.

적으로 가하였다(Fig. 2B). \#47이 원심방향으로 충분히 직립된 이후에 통상적인 교정치료로 배열을 마무리하였 다(Fig. 2C, 2D).

\section{증례 2}

\section{초진 상태와 치료계획}

18세 남환이 어금니가 나지 않는다는 것을 주소로 내 원하였다. 초진 구강내 검사와 표준 치근단 방사선 사 진 검사에서 \#47이 구강내에서 치관이 아주 조금 보이
는 상태로 근심경사 매복되어 있었으며 \#48이 확인되었 다(Fig. 3). 방사선 사진에서 \#47의 치관 상방에 치조골 이 보이지 않고, 상부의 치은조직이 그다지 두껍지 않을 것으로 판단되어 고주파 전기소작술로 치은조직을 제거 하고 \#47의 치관을 노출시킨 다음 교정장치를 부착하여 직립하기로 하였다. \#48은 치관부만 형성된 초기 발육상 태이며, \#47과 약간 떨어져 있어서 \#47의 직립에 영향을 주지 않을 것으로 판단하여 발치하지 않기로 하였으며, 치료 도중에 직립에 방해될 경우 발치가 필요함을 보호 자에게 설명하였다.
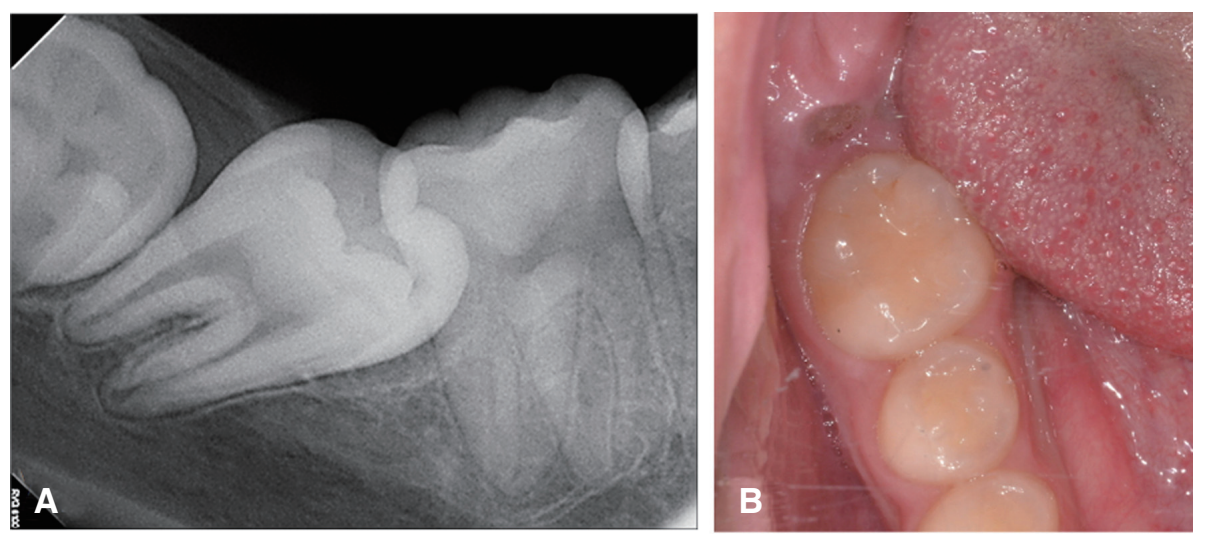

Fig. 3. Pretreatment periapical radiograph (A), intraoral photograph (B). Periapical radiograph was shown mesial angulated impaction of \#47, \#48 was developed at distal side of \#47. Remarkable periodotal or carious lesion were not shown. The ulcerative lesion by erupted \#47's distal cusp was shown at \#46 distal side in intraoral photograph. 


\section{치료 과정}

전달마취하에서 고주파 전기소작기(UM-240RF, Union medical, Yangjoo, Korea)로 \#47 치관 상부의 치 은을 절제하여 장치를 부착할 정도로 치관을 노출시켰 다. 노출된 \#47 교합면의 가장 근심부에 lingual button 을 부착하였으며, 견인방향을 \#47의 직후방 원심쪽으 로 쉽게 조절할 수 있도록 견인 $\mathrm{arm}$ 을 교체 가능한 형태 로 변형한 humpery 장치를 \#46에 장착하고 견인 arm과 lingual button간에 탄성체인을 연결하여 \#47을 원심방 향으로 견인하였다(Fig. 4A, 4B). 원심방향의 경사이동과 정출이 발생하여 \#47이 충분히 직립되면서 치관의 협측 면이 교정장치를 부착할 만큼 노출되었을 때 증례 1에서 처럼 .018" bracket과 tube를 부착하고 부분 호선을 이용 하여 통상적인 배열을 마무리하였으며, 제 3 대구치는 치 료에 방해되지 않아 주기적으로 관찰하기로 하였다(Fig. 4C - 4E).

\section{증례 3}

초진 상태와 치료계획

14세 여환이 전반적인 교정치료를 위하여 내원하였다. 교정치료를 위한 검사에서 약간의 총생과 전치부 교차교 합과 더불어 \#47이 구강내에서 치관이 보이지 않는 상태 로 근심경사 매복되어 있었으며, panoramic view 방사선 사진에서 \#47의 원심부 가까이에 \#48이 존재하여 \#47 의 직립에 방해될 것으로 판단하였다(Fig. 5). 이에 전층 피판을 형성하여 \#48을 발치하고 확보된 후방 공간을 이용하여 직립하기로 하였으며, 보호자에게 직립을 위해 서 증례 2에서 처럼 humpery 장치와 치은 절제술이 필요 함을 설명하였다.

\section{치료과정}

전달마취하에서 전층피판을 형성하고 \#48을 발치하였
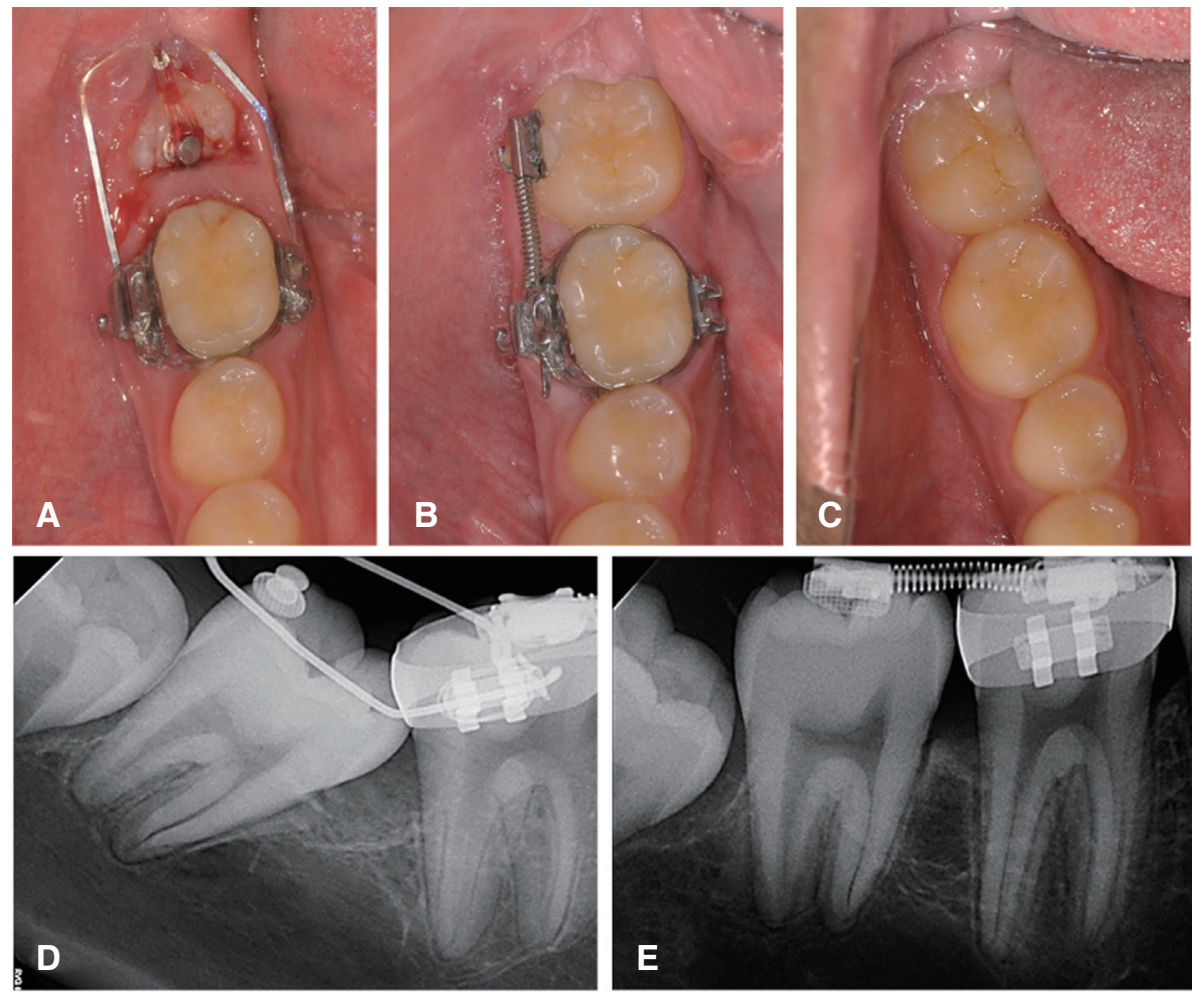

Fig. 4. Intraoral photographs, periapical radiographs during treat of mesioangulated impaction of \#47. Each intraoral photographs were cropped. (A) \& (B) After gingivectomy, occlusal surface of \#47 was exposed. A lingual button was bonded on most mesial side, Modified Humpery appliance was cemented on \#46 and tractional elastic module was engaged. (C) \& (D) After gross uprighting process, lingual button, Humpery appliance's lever arm were removed. .018 standard tube was bonded on right position of \#47. Partial .016 $\times .022 \mathrm{SS}$ wire and open coil was delivered. There were no periodontal problem, root resorption of \#47. \#48 was developed normally at \#47 distal area. (E) After treatment. The mesioangulated \#47 was uprighted to right position. Slightly gingival swelling was shown at \#47 distal surface. 

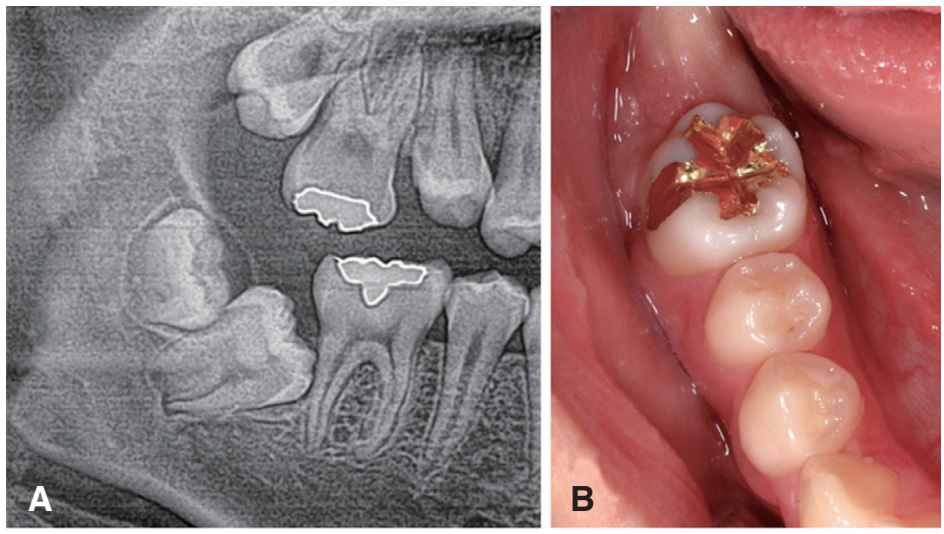

Fig. 5. Pretreatment panoramic radiograph $(A)$, intraoral photograph (B). Panoramic radiograph was shown mesial angulated impaction of \#47, \#48 was developing at closed distal side of \#47.
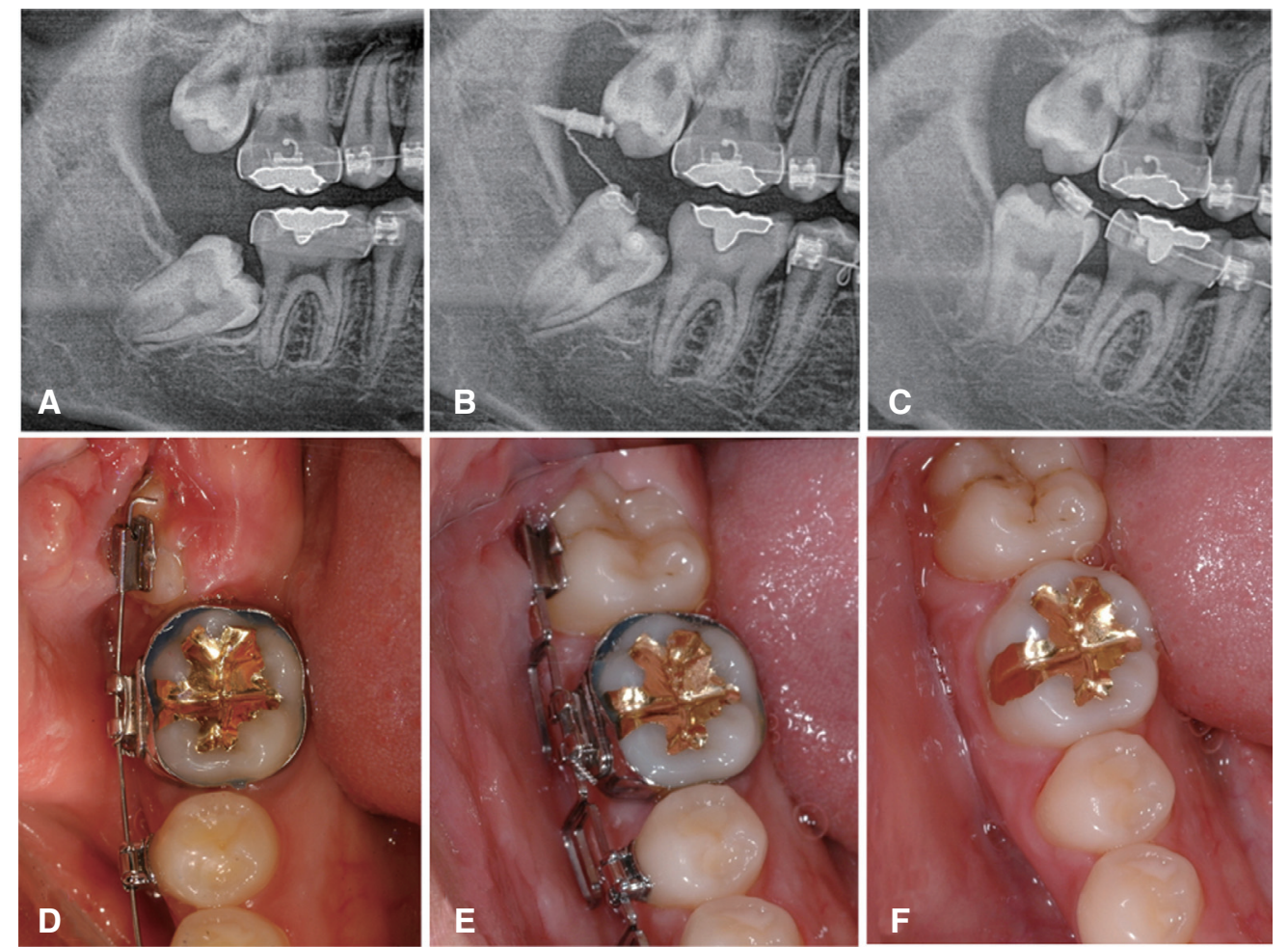

Fig. 6. Intraoral photographs, panoramic radiographs during treat of mesioangulated impaction of \#47. Each images were cropped. (A) 1 year later after \#48 extraction. (B) Mini-implant was inserted at most anterior-inferior border mandibular ramus, then $0.3 \mathrm{~mm}$ dead soft SS wire was connected to mini-implant. Elastic chain was engaged between $0.3 \mathrm{~mm}$ wire and lingual button that was bonded on \#47 occlusal surface. (C) \& (D) After gross uprighting process, lingual button, mini-implant were removed, then a .018 standard tube was bonded on right position of \#47, continuous arch wire was engaged. (E) MEAW was used at finishing stage. (F) After treatment. The mesioangulated \#47 was uprighted to right position.

다. 이후에 환자가 1 년 정도 내원하지 않아 치료가 지연 되었다. 환자가 재내원시에 \#48을 발치하고 1년 정도 시 간이 지났지만 \#47의 위치는 변화하지 않았다(Fig. 6A). 이에 직립을 위해 발치와 후방부 하악골 상행지 전연에
골격성 고정원을 식립하여 안정적인 고정원을 확보하고 \#47을 후방으로 견인하여 직립하기로 치료계획을 변경 하였다. 다시 전층피판을 형성하고 발치와의 후상방 부 위의 하악골 상행지 전연에 골격성 고정원(JA type, 1.6 
$\times 8 \mathrm{~mm}$, Jeil medical Co. Ltd., Seoul, Korea)을 식립하 였다. 식립의 위치는 가능한 원심협측으로 정하여 직립시 치아가 걸리지 않도록 유의하였다. 또 이때 노출된 \#47 치관부에 lingual button을 직접접착술로 부착하고 골격 성 고정원과 button간에 탄성체인(Energy chain-Closed type, RMO, Denver, USA)을 연결하여 견인을 시작하였 다(Fig. $6 \mathrm{~B})$. 견인이 진행됨에 따라 견인용 호선과 탄성체 인이 노출되었고 동시에 \#47도 원심방향 경사이동과 함 께 정출되어 치관 협측부가 장치를 부착할 만큼 노출되 었다. 이에 앞의 다른 증례처럼 .022" bracket과 tube를 부착하고 MEAW 장치를 이용하여 통상적인 배열을 마 무리하였다(Fig. 6C - 6F).

\section{증례 4}

초진 상태와 치료 계획

19세 남환이 어금니에 음식물이 끼고 아프다는 것을
주소로 보존과에 내원하였다가 직립치료가 필요하다는 판단하에 교정과로 의뢰되었다. \#47이 중등도의 치아우 식증을 가지고 근심경사 매복되어 있었으며, \#48이 바로 후방에서 맹출된 상태였다(Fig. 7). \#47의 통증조절을 위 하여 근관치료가 필요하였지만, 기구의 접근이 매우 제 한되어 정상적인 근관치료가 어렵다는 보존과의 판단에 따라 \#47을 발치하고 \#48을 근심으로 견인하기로 하였 다. \#48의 근심 견인시 과도한 근심 경사를 막기 위하여 helix loop을 적용하여 tip back moment를 부여하기로 하였다.

\section{치료과정}

발치기구의 접근이 제한되어 \#47을 분할하여 발치 하였으며, 협측치조골 손실에 주의하였다. 발사 이후에 \#48, 46, 45, 44에 .022" bracket과 tube를 직접접착술로 부착하였다. 초탄성 호선을 .016" × .022", .019" × .025" 순서로 사용하여 배열하였으며(Fig. 8A), 이후에 helix
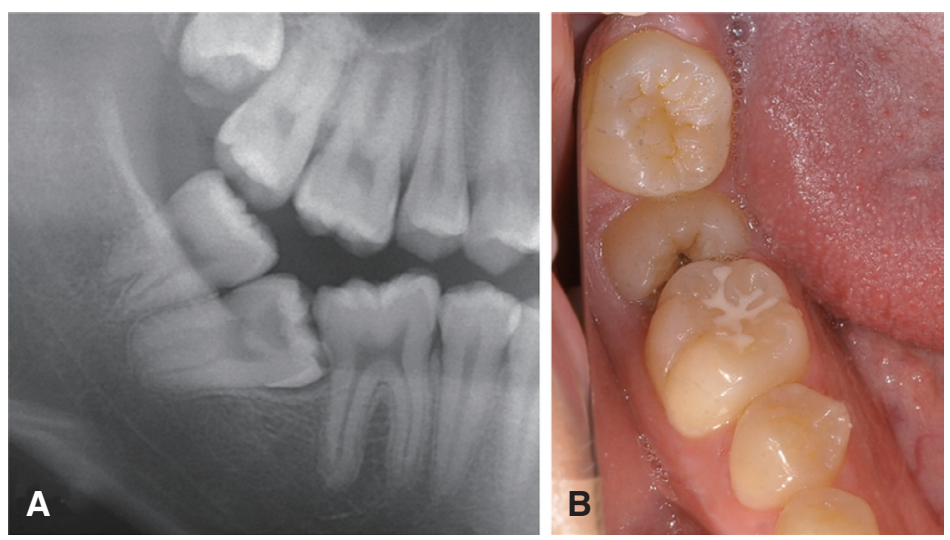

Fig. 7. Pretreatment panoramic radiograph $(A)$, intraoral photograph (B). Panoramic radiograph was shown almost horizontal angulated impaction of \#47. Fully developed \#48 was erupted at right distal side of \#47. It was occluded \#17. Deep caries lesion was shown panoramic view, intraoral photograph.
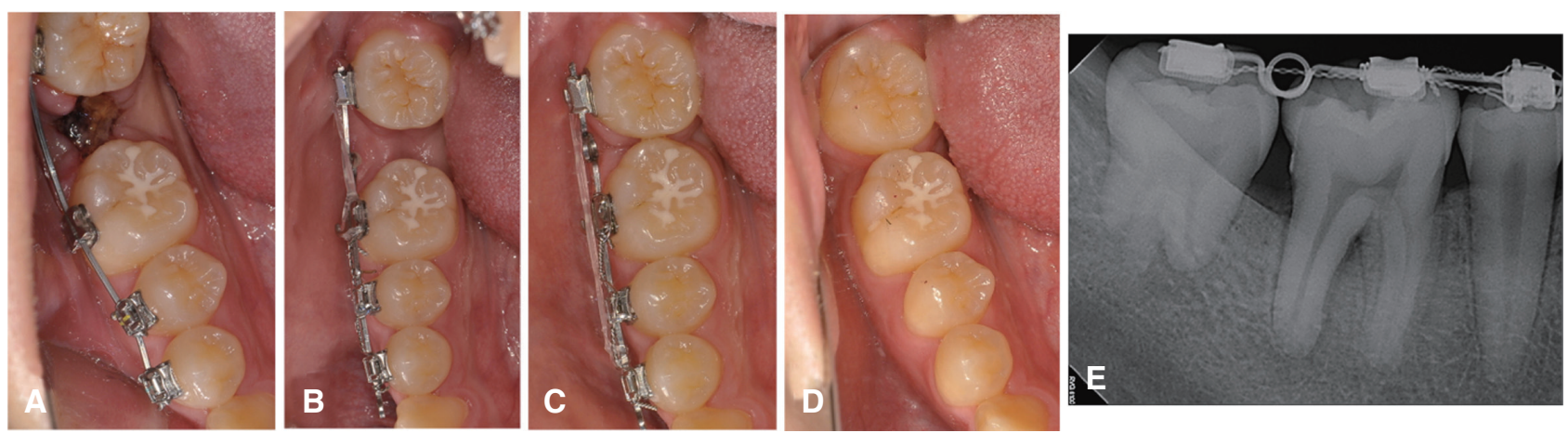

Fig. 8. Intraoral photographs, periapical radiograph during traction of \#48. Each intraoral photographs were cropped. (A) After \#47 extraction. .022 SWA bracket bonded on \#44 - 48, then .016 ×.022 Niti was engaged. (B) After initial alignment, .019 ×.025 SS with helix loop was engaged for distal tip-back moment during mesial traction procedure by elastic chain. (C) Traction process of \#48 was almost finished. (D) After treatment. \#48 was tracted to \#47's position. (E) Periapical radiograph after traction of \#48. The long axis of \#48 was well controlled. However, slightly root resorption was happened. 
loop을 굴곡한 .019" × .025" SS wire를 결찰하여 \#48을 원심방향으로 치관 경사시키면서, 탄성체인을 전방부 치 열에 연결하여 근심으로 견인하였으며(Fig. 8B - 8E), 근 심견인이 완료된 후 미세한 위치조절을 시행하면서 치료 를 마무리 하였다.

\section{고찰}

근심경사 매복된 하악 제 2 대구치를 직립하기 위해 가 장 먼저 생각할 문제는 “제 2 대구치를 직립하여 사용할 수 있는 가?” 일 것이다. 이는 근관치료시 치료후 지대치 로 사용 가능성을 먼저 판단하는 것과 유사한 것으로, 직 립의 성공여부와 별도로 직립 후 대구치로서 저작기능을 수행할 수 있을 것인가에 대한 평가가 필요하다. 저작기 능에 문제가 없다면 당연히 직립에 대해 고민해야 겠지 만, 그렇지 못하다면 발치후 수복에 대해 고려해 보아야 할 것이다. ${ }^{8}$ 본 보고의 4 번째 증례에서도 근심경사 매복 된 제 2 대구치에 중등도 이상의 치아우식증이 존재하여 예후가 좋지 않을 것으로 판단하고 이를 발치하고 후방 에 있는 제 3 대구치를 근심으로 견인하여 사용하기로 치 료계획을 결정하였다. 이처럼 후방에 제 3 대구치가 있다 면 이를 근심으로 견인하는 것도 수복치료와 비슷한 대 안이 될 수 있다. 제 3 대구치가 존재하지 않으며 매복된 제 2 대구치를 발치해야 한다면 임플란트 등으로 수복해 야 할 것이다.

매복된 제 2 대구치를 직립하기로 결정하였다면, 이를 방해하는 요소들에 관해 생각해 보아야 한다. 가장 흔한 방해요소로 원심부에 있는 제 3 대구치이다. 근심매복된 제 2 대구치를 직립할 때의 역학상 약간의 원심이동이 발 생하게 되며 제 3 대구치가 너무 직후방에 존재한다면, 직 립에 방해가 될 수 있다. 직립에 방해가 된다면 3대구치 를 발치해야겠지만, 발육이 초기단계이거나 2대구치 까 지 약간 떨어져 있다면, 발치에 따른 환자의 외상을 고려 해 볼 때 발치 시기를 늦추는 것도 가능하다. 또한 생역 학적으로 볼 때, 근심경사 매복된 제 2 대구치의 직립시 치 관은 원심측으로, 치근은 근심측으로 가는 회전형태의 이동이기 때문에 제 3 대구치를 반드시 발치할 필요는 없 을 것으로 생각된다. Wellfelt와 Varpio는 제2대구치의 외 과적 노출술의 유용성을 설명하면서 제 3 대구치의 발치 가 반드시 필요한 것은 아니라고 하였지만, ${ }^{9}$ Andreasen 등은 제 3 대구치 치배의 발거는 제 2 대구치의 맹출 공간 을 확보해 준다는 점에서 의미가 있으며, 제 3 대구치 치배
를 발거한 후 제 2 대구치를 외과적으로 노출시키는 것이 맹출에 도움을 준다고 하였다. ${ }^{2}$ 본 보고의 2 번째 증례에 서는 제 3 대구치가 존재하였지만, 제 2 대구치의 직립 치료 에는 별다른 영향이 없었다. 반면에 3번째 증례에서는 제 3 대구치가 존재하여 직립에 방해가 될 것으로 생각되어 이를 발치하고 제 2 대구치를 직립하였다. 임상적인 판단 으로 3대구치가 직립에 방해될 것으로 생각될 경우 발치 하는 것이 유리할 것이며, 이때 전층피판 거상으로 노출 된 하악지의 전연부에 골격성 고정원을 식립하여 사용하 는 것도 치료에 도움이 될 수 있을 것이다. ${ }^{10}$ 본 증례보고 의 증례 3 에서도 후방에 존재하는 제 3 대구치를 발치하고 동시에 골격성 고정원을 식립하여 제 2 대구치의 직립에 사용하였다. 만약 제 3 대구치를 발치하지 않고 2대구치를 직립한다면, 차후에 제 3 대구치의 맹출공간이 감소되어 제 3 대구치의 매복이 발생할 수 있음을 환자나 보호자에 게 주지시킬 필요가 있을 것이다.

또다른 고려 사항으로 제 2 대구치의 출은여부이다. 제 2 대구치가 출은되어 있다면 교정장치를 부착하여 직립할 수 있을 것이지만, 그렇지 않다면 치은 절제술로 치관부 를 노출시키고 장치를 부착하여야 한다. 이때 전통적으 로 메스를 사용하거나 고주파 전기소작기, ${ }^{11}$ 레이져 ${ }^{12}$ 도 사용되고 있다. 증례 1 에서는 장치를 부착하기에 충분 할 정도로 치관이 노출되어 있어서 바로 장치를 부착하 였지만, 증례 2에서는 치은을 절제하여 치관부를 노출시 켜야 했기 때문에 사용의 편리성과 출혈 조절등을 고려 하여 고주파 전기소작기를 사용하여 치은조직을 절제하 였으며, 세번째 증례에서는 치관이 노출되어 있지 않았지 만, 제 2 대구치 치관부에 장치를 부착하고 폐쇄형 방법으 로 직립할 계획이었기 때문에 치은을 보존할 수 있는 전 통적인 메스를 사용하는 방법으로 치은을 절개하고 다시 봉합하였다.

\section{결론}

저자는 근심경사 매복된 하악 제 2 대구치를 다양한 방 법으로 직립하는 치료를 통해 다음과 같은 지견들을 얻 을 수 있었다.

1. 근심경사 매복된 하악 제 2 대구치의 치관이 조금이 라도 보일 경우 가능한 위치에 장치를 부착하고 직 립해 가면서 장치의 위치를 조절하여 성공적으로 치 료할 수 있다.

2. 제 3 대구치가 존재하여도 직립치료에 방해되지 않을 
수 있으므로 치료 초기에 발치를 하기보다는 제 2 대 구치를 직립하면서 관찰해 볼 필요가 있다.

3. 제 2 대구치의 직립이 어렵거나 치아우식증등으로 예 후가 불량할 경우 제 2 대구치를 발치하고 제 3 대구치 를 견인하여 사용할 수도 있다.

\section{ORCID}

Baekgue Choi http://ordid.org/0000-0003-2913-8786

Dongkee Jeong http://ordid.org/0000-0001-8049-3180

Sunghoon Lim http://ordid.org/0000-0003-4528-8514

Sungnam Gang http://ordid.org/0000-0002-1608-9199

\section{References}

1. Lee HL, Lee KH, La JY, An SY, Kim YH, Lim HS, Lee JW. Eruption guidance of impacted mandibular second molar. J Korean Acad Pediatr Dent 2012;39:404-11.

2. Andreasen JO, Peterson J, Laskin DM. Textbook and color atlas of tooth impactions. Copenhagen; Munksgaard; 1997. p. 198-216.

3. Grover PS, Lorton L. The incidence of unerupted permanent teeth and related clinical cases. Oral Surg Oral Med Oral Pathol 1985;59:420-5.

4. Bondemark L, Tsiopa J. Prevalence of ectopic eruption, impaction, retention and agenesis of the per- manent second molar. Angle Orthod 2007;77:7738.

5. Nanci A. Ten Cate's oral histology: development, structure, and function. 7th ed. St. Louis: Elsevier Health Sciences 2007.

6. Fu PS, Wang JC, Wu YM, Huang TK, Chen WC, Tseng YC, Tseng CH, Hung CC. Impacted mandibular second molars. Angle Orthod 2012;82:6705.

7. Raghoebar GM, Boering G, Vissink A, Stegenga B. Eruption disturbances of permanent molars: a review. J Oral Pathol Med 1991;20:159-66.

8. Sawicka M, Racka-Pilszak B, Rosnowska-Mazurkiewicz A. Uprighting partially impacted permanent second molars. Angle Orthod 2007;77:148-54.

9. Wellfelt B, Varpio M. Disturbed eruption of the permanent lower second molar: treatment and results. ASDC J Dent Child 1988;55:183-9.

10. Park HS, Kyung HM, Sung JH. A simple method of molar uprighting with micro-implant anchorage. J Clin Orthod 2002;36:592-6.

11. Babaji P, Singh V, Chaurasia VR, Jawale MR. Electro surgery in dentistry: report of cases. J Pediatr Dent 20142:20-4.

12. Mavrogiannis M, Ellis J, Seymour RA, Thomason JM. The efficacy of three different surgical techniques in the management of drug induced gingival overgrowth. J Clin Periodontol 2006;33:677-82. 


\section{근심경사 매복된 하악 제2대구치의 직립 치료}

\section{최백규 ${ }^{1,2}$, 정동기 ${ }^{2}$ 임성훈 ${ }^{3}$, 강성남 ${ }^{4 *}$}

${ }^{1}$ 가지런한 $\mathrm{S}$ 치과의원

${ }^{2}$ 조선대학교 치과대학 대학원

${ }^{3}$ 거제부부치과의원

${ }^{4}$ 조선대학교 치과대학 치과교정학교실

매복된 하악 제 2 대구치의 임상적 증상은 제 3 대구치의 매복 상황과 유사하나 발치가 주된 치료법인 제 3 대구치와 달리 저 작기능의 회복, 대칭적인 안면 성장, 치열궁의 대칭성 유지, 안정된 교합관계 회복등을 위하여 가능한 직립하여야 한다는 점에서 치료 방법이 다르다. 매복 하악 제 2 대구치의 직립 치료시 치질의 노출 정도, 직립에 방해되는 제 3 대구치의 존재여 부, 제 2 대구치의 예후, 대합치의 정출여부 등에 따라 치료 전략이 달라야 하며, 이러한 전략에 따라 사용하는 장치와 고 정원의 종류도 결정된다. 심미적 개선은 기대하기 어렵지만, 저작기능을 회복하고 치아우식증, 치주질환, 악관절 장애등 여러 문제를 예방할 수 있는 하악 제 2 대구치 직립은 기능회복과 질환의 예방이라는 관점에서 중요한 치료이다.

(구강회복응용과학지 2017;33(1):25-33)

주요어: 하악 제 2 대구치 매복; 교정적 직립 치료; 부분교정치료

*교신저자: 강성남

(61452)광주시 동구 필문대로 309 조선대학교 치과대학 치과교정학교실

Tel: 062-220-3874 | Fax: 062-226-3090 | E-mail: 022bracket@gmail.com

접수일: 2016년 11월 11일 | 수정일: 2017년 2월 5일 | 채택일: 2017년 2월 9일 